\title{
Rare long-distance dispersal of a marine angiosperm across the Pacific Ocean
}

\author{
Timothy M. Smith1,2 (D) | Paul H. York ${ }^{1,3}$ | Bernardo R. Broitman4,5 (D) | \\ Martin Thiele,5,6 | Graeme C. Hays ${ }^{1}$ | Erik van Sebille7,8,9 | \\ Nathan F. Putman ${ }^{10,11,12}$ | Peter I. Macreadie ${ }^{1}$ | Craig D. H. Sherman ${ }^{1}$ \\ ${ }^{1}$ School of Life and Environmental Sciences, Centre for Integrative Ecology, Deakin University, Waurn Ponds, Victoria, Australia \\ ${ }^{2}$ School of Environmental and Life Sciences, University of Newcastle, Ourimbah, New South Wales, Australia \\ ${ }^{3}$ Centre for Tropical Water \& Aquatic Ecosystem Research (TropWATER), James Cook University, Cairns, Queensland, Australia \\ ${ }^{4}$ Centro de Estudios Avanzados en Zonas Áridas (CEAZA), Universidad Católica del Norte, Coquimbo, Chile \\ ${ }^{5}$ Facultad Ciencias del Mar, Universidad Católica del Norte, Larrondo, Coquimbo, Chile \\ ${ }^{6}$ Millennium Nucleus Ecology and Sustainable Management of Oceanic Island (ESMOI), Coquimbo, Chile \\ ${ }^{7}$ Department of Physics, Grantham Institute, Imperial College London, London, United Kingdom \\ ${ }^{8}$ ARC Centre of Excellence for Climate System Science, Climate Change Research Centre, University of New South Wales, Sydney, Australia \\ ${ }^{9}$ Institute for Marine and Atmospheric Research Utrecht, Utrecht University, Utrecht, Netherlands \\ ${ }^{10}$ LGL Ecological Research Associates Inc, Bryan, Texas \\ ${ }^{11}$ Cooperative Institute for Marine and Atmospheric Studies, University of Miami, Miami, Florida \\ ${ }^{12}$ Atlantic Oceanographic and Meteorological Laboratory, National Oceanic and Atmospheric Administration, Miami, Florida
}

\section{Correspondence}

Timothy M. Smith, School of Environmental and Life Sciences, University of Newcastle, 10 Chittaway Rd, Ourimbah, New South

Wales, 2258, Australia.

Email: tim.m.smith@newcastle.edu.au

Funding information

Deakin University School of Environmental

Sciences; Australian Research Council

DECRA; European Research Council,

Grant/Award Number: 715386; NOAA's

Atlantic Oceanographic \& Meteorological

Laboratory

Editor: Brody Sandel

\begin{abstract}
Aim: Long-distance dispersal (LDD) events occur rarely but play a fundamental role in shaping species biogeography. Lying at the heart of island biogeography theory, LDD relies on unusual events to facilitate colonization of new habitats and range expansion. Despite the importance of LDD, it is inherently difficult to quantify due to the rarity of such events. We estimate the probability of LDD of the seagrass Heterozostera nigricaulis, a common Australian species, across the Pacific Ocean to colonize South America.
\end{abstract}

Location: Coastal Chile, Australia and the Pacific Ocean.

Methods: Genetic analyses of $\mathrm{H}$. nigricaulis collected from Chile and Australia were used to assess the relationship between the populations and levels of clonality. Ocean surface current models were used to predict the probability of propagules dispersing from south-east Australia to central Chile and shipping data used to determine the likelihood of anthropogenic dispersal.

Results: Our study infers that the seagrass $H$. nigricaulis dispersed from Australia across the entire width of the Pacific (c. 14,000 km) to colonize South America on two occasions. Genetic analyses reveal that these events led to two large isolated clones, one of which covers a combined area of $3.47 \mathrm{~km}^{2}$. Oceanographic models estimate the arrival probability of a dispersal propagule within 3 years to be at most $0.00264 \%$. Early shipping provides a potential alternative dispersal vector, yet few ships sailed from SE Australia to Chile prior to the first recording of $H$. nigricaulis and the lack of more recent and ongoing introductions demonstrate the rarity of such dispersal.

Main conclusions: These findings demonstrate LDD does occur over extreme distances despite very low probabilities. The large number of propagules (100s of millions) produced over 100 s of 
years suggests that the arrival of propagules in Chile was inevitable and confirms the importance of LDD for species distributions and community ecology.

\section{KEYWORDS}

biogeography, clonal organisms, long distance dispersal, oceanography, seagrass

\section{1 | INTRODUCTION}

Dispersal is central to our understanding of species distributions and plays a key role in island biogeography theory by determining rates of immigration. Over vast expanses, immigration is predicted to be low, decreasing as distance increases (Nathan et al., 2008). Many species distributions, however, are greater than those predicted via dispersal, leading to long-distance dispersal (LDD) being dismissed as improbable in favor of biogeographic vicariance (de Queiroz, 2005). Recently, molecular tools have identified mismatched evolutionary and geographic time-scales in species distributions leading to the re-emergence of LDD theory (de Queiroz, 2005; Sanmartin \& Ronquist, 2004). Despite the low probability of successful dispersal over large distances, LDD theory predicts rare events such as cyclones, floods or unusual vectors can facilitate species dispersal beyond their normal range (Gillespie et al., 2012; Nathan, 2006). Given the large number of species (1 $\times 10^{6} \mathrm{~s}$ ) and the occurrence of rare dispersal events over evolutionarily important time-scales (100s to 1000 s of years) it would be expected that LDD events will occur despite probabilities approaching zero. This is akin to a lottery where the chance of a particular individual winning is extremely low, but the probability that someone wins is high.

The arrival of a species into a new area can have profound impacts on local ecological communities, leading to novel interactions and altered environmental conditions that can have beneficial or detrimental effects to native species (Rodriguez, 2006; Vilà et al., 2011). For habitat-forming species (so-called ecosystem engineers) such impacts are even more pronounced as they can provide alternative habitats for local species and introduce novel ecosystem services (Castilla, Lagos, \& Cerda, 2004). For instance the arrival of a habitat-forming tunicate (Pyura praeputialis) in Chile from Australia has increased biodiversity within the intertidal zone and shifted the distribution of native habitat-forming mussels and kelps (Castilla et al., 2004, 2014). In such cases the introduction of a new species via LDD not only provides it with unique opportunities for habitat exploitation, but it also provides local species the opportunity to exploit the new habitat and ecosystem services it provides.

Seagrasses are marine angiosperms that act as coastal ecosystem engineers and provide a variety of ecosystem services such as habitat provision, sediment stabilization, nutrient cycling and carbon storage (Orth et al., 2006). Seagrass dispersal is often limited by the production of small non-buoyant seeds or asexual growth; however, a number of strategies have evolved to allow dispersal over greater distances (Kendrick et al., 2012, 2017). Floating seeds and fruit occur in several species (i.e. Posidonia) that can be dispersed large distances (100s of $\mathrm{km}$ ) via wind and currents (McMahon et al., 2014). LDD also occurs in species with negatively buoyant seeds (i.e. Zostera) where seeds are carried on reproductive shoots or spathes that become detached and disperse into new habitats or locations (Harwell \& Orth, 2002; Källström, Nyqvist, Åberg, Bodin, \& André, 2008; McMahon et al., 2014). Alternatively, dispersal can occur asexually as detached vegetative fragments (rhizomes and leaves), or in some cases specialized asexual vegetative propagules (i.e. Heterozostera), drift in or on the water column and settle in new locations where they are able to establish and develop into functioning plants (Kendrick et al., 2017; Thomson et al., 2015). The development of a variety of dispersal mechanisms has allowed seagrasses to disperse over distances ranging from a few $\mathrm{cm}$ to $100 \mathrm{~s}$ of $\mathrm{km}$ to become one of the most conspicuous and important nearshore ecosystems across the globe (Kendrick et al., 2012, 2017).

Seagrass is absent along the temperate Pacific coast of South America with the exception of three small patches $\left(0.036-2.277 \mathrm{~km}^{2}\right)$ in Chile. Recent molecular analysis has confirmed this seagrass as Heterozostera nigricaulis (syn. Zostera nigricaulis, Heterozostera tasmanica), a common species in southern Australia (Coyer et al., 2013) where it forms large meadows that produce large quantities of non-buoyant seeds and specialized vegetative rhizomes used for dispersal that can remain viable in the water column for more than 3 months (Smith et al., 2016; Thomson et al., 2015). Chilean H. nigricaulis populations were thought to be prehistoric relics (Velez-Juarbe, 2013) but the complete lack of genetic divergence at key chloroplast and nuclear genes suggests these populations are recent arrivals from Australia and not relic populations (Coyer et al., 2013). Colonization of $H$. nigricaulis from Australia may have occurred via ocean currents or through shipping. Here we use multiple lines of evidence, including molecular data, Lagrangian drifter trajectories, ocean circulation models and shipping records, to provide the first estimates of the probability of long-distance dispersal and discuss the role of these events in shaping ecosystem structure.

\section{2 | MATERIALS AND METHODS}

Heterozostera nigricaulis is known to occur at three sites in Chile. Puerto

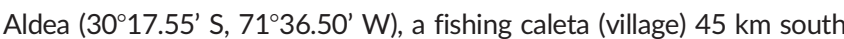
of Coquimbo that is protected from onshore winds and waves; Bahia Chascos $\left(27^{\circ} 41.32^{\prime} \mathrm{S}, 71^{\circ} \mathrm{O} .43^{\prime} \mathrm{W}\right)$, a small fishing caleta $295 \mathrm{~km}$ north of Puerto Aldea; and Isla Damas (29 $14.18^{\prime}$ S, $71^{\circ} 31.90^{\prime}$ W), 5 km offshore within the Humboldt Penguin National Reserve and $120 \mathrm{~km}$ north of Puerto Aldea.

To determine the structure and patterns of genotypic diversity within $\mathrm{H}$. nigricaulis populations, 30-60 samples were haphazardly collected at each of the three sites. Ten samples were collected from each of six $10 \mathrm{~m} \times 10 \mathrm{~m}$ quadrats at Puerto Aldea and 10 samples collected from each of three quadrats at both Bahia Chascos and Isla Damas. 
Quadrats were distributed across the entire seagrass meadow at each site in order to maximize our ability to quantify levels of genotypic diversity. An additional 18 drift samples were collected from two sites approximately $40 \mathrm{~km}$ offshore from Coquimbo (2947.38' S, $71^{\circ} 46.15^{\prime} \mathrm{W}$ and $30^{\circ} 0.59^{\prime} \mathrm{S}, 71^{\circ} 34.26^{\prime} \mathrm{W}$ ) to determine where floating samples were originating. All samples consisted of at least $10 \mathrm{~cm}$ of leaf obtained from a single stem. Samples were cleaned and any excess water removed before samples were desiccated with silica beads.

Collections of $\mathrm{H}$. nigricaulis were also made from 25 sites in southeastern (SE) Australia for assignment tests. These sites were Snug, Triabuna and Flinders Island in Tasmania; Andersons Inlet, Apollo Bay, Portland, Corner Inlet, Western Port and 16 sites (Altona, Avalon, Blairgowrie, Edwards Point, Grand Scenic, Jawbone, Kirk Point, Mud Islands Point Henry, Point Lonsdale, Point Richards, Ricketts Point, Rosebud, North Swan Bay, South Swan Bay, Williamstown) in Port Phillip Bay in Victoria; and Jervis Bay in New South Wales. At each Australian site 15 samples were haphazardly collected from each of three $10 \mathrm{~m} \times$ $10 \mathrm{~m}$ quadrats $50-100 \mathrm{~m}$ apart.

\section{1 | DNA extraction and genotyping}

Genomic DNA was isolated from leaf tissue using DNeasy plant kits (Qiagen) following the manufacturer's instructions. All samples were genotyped using nine polymorphic microsatellite markers previously developed for this species; ZosVic49, ZosVic50, ZosVic55, ZosVic60, ZosVic66, ZosVic68, ZosVic69, ZosVic70b and ZosVic71 (Smith et al., 2013). Microsatellites were amplified using a polymerase chain reaction (PCR) conducted in $11 \mu \mathrm{L}$ volumes containing: $10 \mathrm{ng}$ genomic DNA; 5 $\mu \mathrm{L}$ PCR Master Mix (Qiagen) and $4 \mu \mathrm{L}$ primer multiplex $(0.26 \mu \mathrm{M}$ of each forward primer and fluorescent dye, $0.13 \mu \mathrm{M}$ of reverse primer). Thermal cycling conditions for the PCR were; initial hot start at $94^{\circ} \mathrm{C}$ for $15 \mathrm{~min}$; ten cycles of $94{ }^{\circ} \mathrm{C}$ for $45 \mathrm{~s}, 55^{\circ} \mathrm{C}$ for $45 \mathrm{~s}, 72{ }^{\circ} \mathrm{C}$ for $45 \mathrm{~s}$; 10 cycles of $94{ }^{\circ} \mathrm{C}$ for $45 \mathrm{~s}, 53^{\circ} \mathrm{C}$ for $45 \mathrm{~s}, 72^{\circ} \mathrm{C}$ for $45 \mathrm{~s} ; 20$ cycles of $94{ }^{\circ} \mathrm{C}$ for $45 \mathrm{~s}, 50{ }^{\circ} \mathrm{C}$ for $45 \mathrm{~s}, 72{ }^{\circ} \mathrm{C}$ for $45 \mathrm{~s}$; final elongation at $72{ }^{\circ} \mathrm{C}$ for 15 min. PCR was conducted in PCR amplicons electrophoresed using an ABI 3130xl Genetic Analyzer, incorporating LIZ 500 (-250) size standard (Applied Biosystems). Alleles were scored using GenEMAPPER, v3.7 (Applied Biosystems).

\section{2 | Genetic analysis}

Genotypic diversity in Chilean H. nigricaulis was calculated as the number of unique multi-locus genotypes $\left(N_{G}\right)$ relative to the number of samples collected $(n)$ and expressed $\left(R=\frac{\left(N_{G}-1\right)}{(N-1)}\right)$ (Dorken \& Eckert, 2001). Bayesian assignment tests were used to identify the potential Australian source populations of the two Chilean clones using GENECLASS 2 (Piry et al., 2004). We employed the Bayesian criterion of Rannala and Mountain (1997) and exclusion probabilities were calculated following 10,000 simulations of a Monte-Carlo re-sampling algorithm and an alpha of 0.01 (Paetkau, Slade, Burden, \& Estoup, 2004). We computed a likelihood ratio test comparing the population where the individual was sampled over the highest likelihood value among all available populations ( $L=L_{-}$home/L_max).

\section{3 | Sampling seeds and flowers}

At Puerto Aldea above- and below-ground samples were collected to determine the extent of sexual reproduction within the Chilean H. nigricaulis population. Samples were collected in November 2011 to coincide with the highest flowering density in Australian samples (Smith et al., 2016). Within each quadrat assigned for collection of genetic samples three replicate $0.25 \mathrm{~m} \times 0.25 \mathrm{~m}$ above-ground samples and $10-\mathrm{cm}$-diameter cores were haphazardly collected. Aboveground samples were searched for spathes and below-ground cores sieved through a 1000- and 710- $\mu \mathrm{m}$ sieve and under a dissecting microscope any seeds were counted.

\subsection{Oceanic modeling}

Oceanic models were used to determine the likelihood that seagrass fragments could drift across the Pacific Ocean from SE Australia to Chile and the length of time it would take. Results from the modeling data combined with existing biological data of $H$. nigricaulis distribution and vegetative fragment density were used to estimate the number of fragments that could reach Chile over long time periods.

\section{5 | Monte Carlo super-trajectories}

Pathways across the ocean were studied using Monte Carlo supertrajectories (MCSTs, van Sebille, Beal, \& Johns, 2011). These MSCTs are statistical recombinations of short pieces of observed free-floating drifting buoy trajectories from the NOAA Global Drifter Program (Lumpkin $\&$ Pazos, 2007). This dataset consists of more than 17,000 free-floating buoys, whose position is recorded every $6 \mathrm{~h}$. MCSTs are particularly suited to study extreme events, as they provide a statistical representation of the probability of going from any location in the ocean to any other over a certain time span. First, the 17,000 drifter trajectories are cast in a transition matrix $P(i, j)$, which stores the probability of going from a 1-degree grid cell $i$ to another grid cell $j$ in 60 days (van Sebille, 2014). Then, MCSTs are formed in this transition matrix by randomly sampling the transitions, starting at $41^{\circ} \mathrm{S}, 149^{\circ} \mathrm{E}$ and iteratively moving from a cell $i$ to a new grid cell $j$ based on the transition probabilities $P(i, j)$ from the matrix. In this way, 10 million MCSTs were formed, and only those that at some point reached a grid cell adjacent to the Chilean coast were kept. This large number of MCSTs was chosen to adequately sample the variability of oceanographic conditions represented in the drifter dataset from which they were derived.

\subsection{Backtracking models}

Oceanic connectivity between south-east Australia and Chile was estimated using the Global Hybrid Coordinate Ocean Model (HYCOM, Chassignet et al., 2007) and ICHTHYOP (v2) virtual particle tracking software (Lett et al., 2008). HYCOM is forced using wind stress, wind speed, heat flux, precipitation, and river discharge. HYCOM assimilates satellite altimetry data, sea surface temperature and in situ measurements from a global array of expendable bathythermographs, Argo floats, and moored buoys to produce hindcast model outputs. Thus, 
HYCOM accurately resolves mesoscale processes such as meandering currents, fronts, filaments and oceanic eddies (Chassignet et al., 2007). The HYCOM output used here was from the newly released Global Reanalysis (http://hycom.org/dataserver/glb-reanalysis), and output is a daily snapshot of current velocity at 00:00 h (GMT) at a spatial resolution of $0.08^{\circ}$ (approx. 6-9 km grid spacing) - sufficiently high resolution to depict ocean circulation processes at scales relevant for depicting organismal transport at the ocean surface (Putman \& He, 2013).

We performed 'backtracking' simulations (e.g. Putman \& NaroMaciel, 2013) in which virtual particles were released along the coast of Chile and tracked backwards through time to determine the probability of transport from southern Australian waters. One release zone spanned the continental coast of Chile $\left(20^{\circ} \mathrm{S}\right.$ to $\left.40^{\circ} \mathrm{S}\right)$. A second release zone was defined between $26^{\circ} \mathrm{S}$ and $31^{\circ} \mathrm{S}$, more tightly bracketing the regions where $H$. nigricaulis is found in Chile. Both zones were constrained between the 100 and $500 \mathrm{~m}$ isobaths. Each day, 45 particles were released from random locations across each of the two zones (90 particles per day) and tracked for 3 years using a Runge-Kutta fourthorder time-stepping method whereby particle positions were calculated every 30 min (Lett et al., 2008). Particles were counted as having originated in SE Australia if they passed between longitudes $140^{\circ} \mathrm{E}$ and $155^{\circ} \mathrm{E}$ and latitudes $32^{\circ} \mathrm{S}$ and $44^{\circ} \mathrm{S}$. A total of 591,300 particles were backtracked for the years 1993 through 2013, a period spanning a wide range of oceanic conditions including multiple El Niño-Southern Oscillation (ENSO) events. The number of particles released and the range of years that simulations covered allowed us to ensure the dispersal scenarios modelled were representative of the dynamic annual variations in ocean circulation that typify the South Pacific.

\section{7 | Shipping data}

Shipping records were assessed to determine if $\mathrm{H}$. nigricaulis could have been translocated to Chile by ship. All ships departing from Port Phillip Bay (the only international port in Victoria at that time) destined for Valparaiso and Concepcion between 1788 (arrival of the first fleet in Sydney) and 1864 (first recording of H. nigricaulis in Chile) were collated. Shipping records were taken from the series Shipping arrivals and departures for Victoria, journal articles by $\operatorname{Bader}(1974,1988)$ and the National Library of Australia newspaper archives (TROVE) using the search terms 'shipping intelligence', 'for Valparaiso' and 'for Concepcion' between 1860 to 1865 for The Argus in Victoria. Ships departing Port Phillip Bay for international ports between 1981 and 2015 were supplied by the Port of Melbourne archives. These dates were used to calculate the probability of $\mathrm{H}$. nigricaulis arrival in Chile via shipping (pre-1864) and provide a contemporary comparison (1981-2015).

\section{3 | RESULTS}

\section{1 | Clonality and genetic assignment}

Microsatellite analysis revealed only two clones in the Chilean populations of $H$. nigricaulis $(R=.0084)$ where all 60 samples from Puerto Aldea and 30 samples from Bahia Chascos consisted of a single clone (clone A) and the 30 samples from Isla Damas a single, different clone (clone B, Figure 1). Different alleles were detected between the two clones at four of the nine loci tested, and three and six loci were heterozygous in clone $A$ and $B$, respectively. All floating samples of $H$. nigricaulis collected from offshore sites were the same genotype as those collected from Puerto Aldea and Bahia Chascos (clone A). Aboveand below-ground seagrass and sediment samples from all sites contained no flowers. The detailed above-below-ground sampling at Puerto Aldea did not reveal any seeds.

Bayesian assignment tests showed low probability of assignment for clone $\mathrm{A}$ to Australian $\mathrm{H}$. nigricaulis populations but a relatively high probability that clone B originated in Port Phillip Bay in SE Australia. The probability of assignment for clone $A$ to Australian populations was less than .081 at all sites with the exception of Rosebud (.128) in Port Phillip Bay. In contrast, clone B had a high probability of originating from Avalon (.639) or Grand Scenic (.602) in Port Phillip Bay where probabilities were much higher than those outside Port Phillip Bay (probability $<.003$, Supporting Information 1). The low confidence

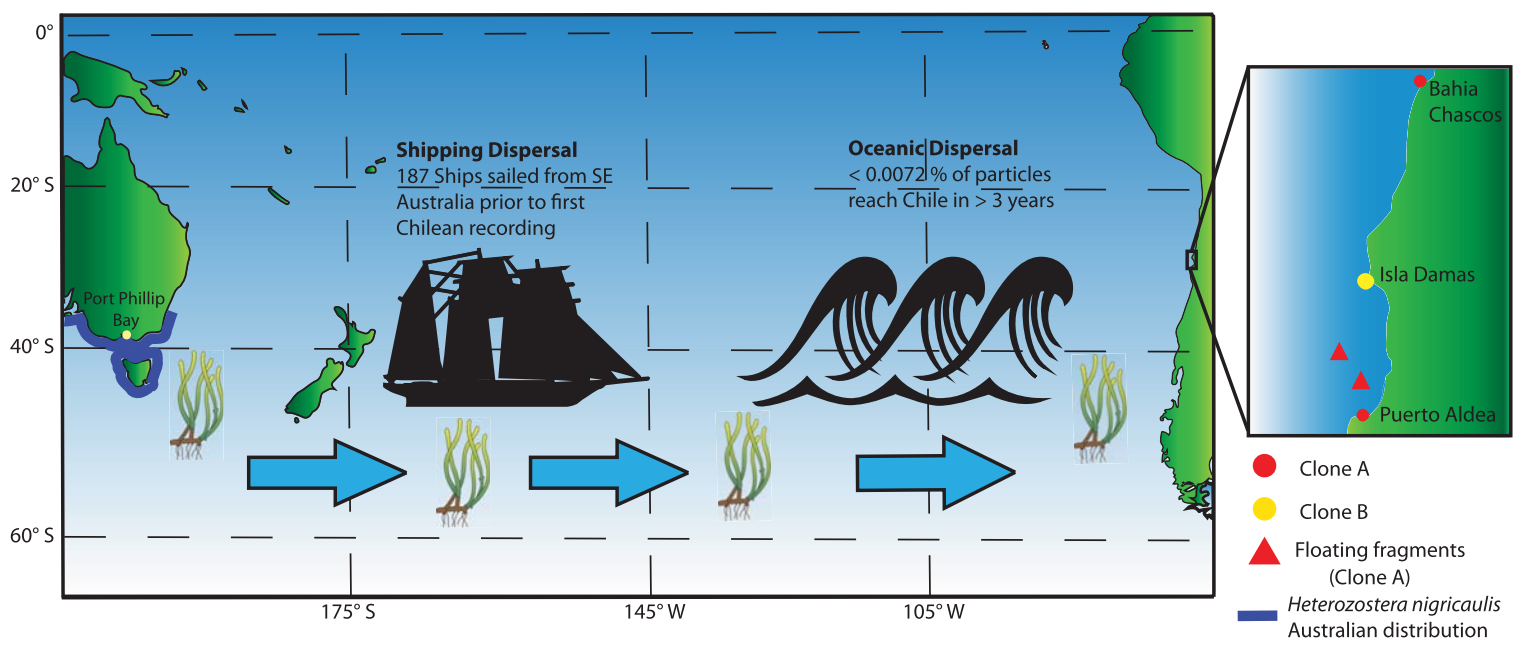

FIGURE 1 Summary of Heterozostera nigricaulis dispersal probabilities across the Pacific Ocean and distribution in Australia and Chile including location of each clone in Chile 
assigned to the origin of clone A suggests that although we sampled 25 sites across H. nigricaulis's geographic range in SE Australia, clone A originated from one of the many areas we did not sample.

\section{2 | Pan-oceanic dispersal}

Oceanic models predicted very low probabilities of particles reaching the Chilean coast. Particles released from SE Australia using the MCST model took at minimum 2 years 4 months to reach the Chilean coast (Figure 2). Of the 10 million particles released $264(0.00264 \%)$ reached the Chilean coast within 3 years (Figure 3). Similarly, the HYCOM 1993-2013 hindcast model predicted 11 of the 591,300 (0.00186\%) particles backtracked from central Chile would arrive in SE Australia within 3 years (Figure 2). Of these 11 particles, seven were released in 1999 and backtracked to Australia in 1997, suggesting that particular oceanic conditions facilitate dispersal over this distance and these dispersal events are related to pulse rather than continuous events.

\subsection{Estimating the number of fragments arriving in Chile}

Port Phillip Bay in SE Australia, where there is a high probability Chile clone $B$ originated from, contains approximately $65 \mathrm{~km}^{2}$ of $\mathrm{H}$. nigricaulis (Blake \& Ball, 2001). Vegetative fragments in $\mathrm{H}$. nigricaulis meadows in Port Phillip Bay can reach densities of $1.8 \times 10^{7} \mathrm{~km}^{2}$ (Thomson et al., 2015) and therefore Port Phillip Bay may contain $1.17 \times 10^{9}$ fragments at any given time. Assuming such densities are annual, over a 100 -year period it could be expected that $1.17 \times 10^{11}$ fragments are produced. Super-trajectory and HYCOM models respectively predict 0.00264 and $0.00186 \%$ of particles will reach Chile from SE Australia, equating to $3.1 \times 10^{8}$ and $2.2 \times 10^{8}$ fragments reaching the continental shelf of Chile over a 100 -year time period.

Shipping records show 187 ships traveled from Port Phillip Bay in SE Australia to the Chilean ports of Conception and Valparaiso prior to 1864 when H. nigricaulis was first recorded in Chile (Supporting Information 2). This number is likely to be lower than the actual number of ships traveling from SE Australia to Chile as whaling ships and ships sailing onto Chile via other ports were not recorded. In contrast, between 1981 and 2015 a total of 46,340 ships departed the Port of Melbourne for ports worldwide (Supporting Information 3).

\section{4 | DISCUSSION}

Seagrass meadows in Chile have extremely low genotypic diversity, consisting of just two clones, one at Puerto Aldea and Bahia Chascos (300 km apart) and another at Isla Damas (located between the two other sites). The presence of these clones $1000 \mathrm{~s}$ of $\mathrm{km}$ from other $H$. nigricaulis populations raises the question 'How did $H$. nigricaulis reach the Chilean coast?'

Biogeographic vicariance produces isolated populations that typically undergo subsequent genetic divergence due to random genetic drift and localized selection. Seagrass was thought to be common on the west coast of South America during the Miocene and before cooling environmental conditions restricted seagrass to the current populations in Chile (Velez-Juarbe, 2013). However, the lack of any sequence divergence at nuclear and chloroplast genes (Coyer et al., 2013) and the complete amplification of microsatellite loci (originally designed for $\mathrm{H}$. nigricaulis Australian populations) indicates a recent introduction of $\mathrm{H}$. nigricaulis into Chile. The two clones detected in Chilean populations are clearly distinct genotypes displaying different alleles at several loci and therefore have not arisen from somatic mutation of a single clone. The high level of heterozygosity in both clones and absence of seed or flowers in this study or previous studies in the Chilean H. nigricaulis population (González \& Edding, 1990; Phillips, Santelices, Bravo, \& McRoy, 1983) indicate the clones are unlikely to be derived from self-fertilization and sexual reproduction within the populations. The lack of co-occurrence of the two clones at any one location suggests two separate colonization events. Oceanic currents are the primary means of LDD for marine species and given favorable conditions allow dispersal over large distances (Kinlan \& Gaines, 2003). Floating rhizomes of $\mathrm{H}$. nigricaulis from clone A were sampled on different occasions (at $40 \mathrm{~km}$ distance from the nearest benthic source population) demonstrating rafting dispersal is a plausible dispersal mechanism connecting the two populations of this clone along the Chilean coast, and possibly also across the South Pacific.

Both oceanic modeling approaches predicted the fastest drift times from SE Australia to central Chile were between 2 and 3 years. Supertrajectory and HYCOM models respectively predicted just 0.00264 and $0.00186 \%$ of particles released would arrive in central Chile within this period, equating to $3.1 \times 10^{8}$ and $2.2 \times 10^{8}$ seagrass fragments from Port Phillip Bay over 100 years. However, both these probabilities are upper bounds, as the models assume no loss of propagules during their trans-basin journey from sinking, herbivory or mortality. Particle arrival near the Chilean coast does not correspond one-to-one to settlement and therefore our estimates of oceanic dispersal are likely overestimations. Seagrass fragments can remain viable and grow floating in the water column over extended periods of time ( $<3$ months) but can also become negatively buoyant, non-viable or release seeds over time (Berković et al., 2014; Harwell \& Orth, 2002; Stafford-Bell, Chariton, \& Robinson, 2015; Thomson et al., 2015), which is not accounted for in the model and therefore far fewer fragments will actually reach Chile. Furthermore, reaching the Chilean coast does not equate to colonization. Propagule survival once settled is low, and, fragments must settle in a suitable environment for establishment, further reducing the odds of LDD (Hall, Hanisak, \& Virnstein, 2006; Thomson et al., 2015). Further research to better understand fragment survival, viability and colonization will provide better estimations of seagrass LDD; however, it is clear that by producing vast amounts of propagules over long time periods $\mathrm{H}$. nigricaulis has been able to increase the length of its distribution tail and succeeded in extreme LDD.

Over long time periods (100s to 1000 s of years) extreme conditions or atypical events (e.g. severe storms) may markedly reduce dispersal duration, allowing dispersal across the Pacific (Gillespie et al., 2012; Nathan, 2006). The shortest time the models predicted a seagrass fragment could cross the Pacific Ocean was 2.5 years, much longer than the length of time a fragment has been recorded floating 


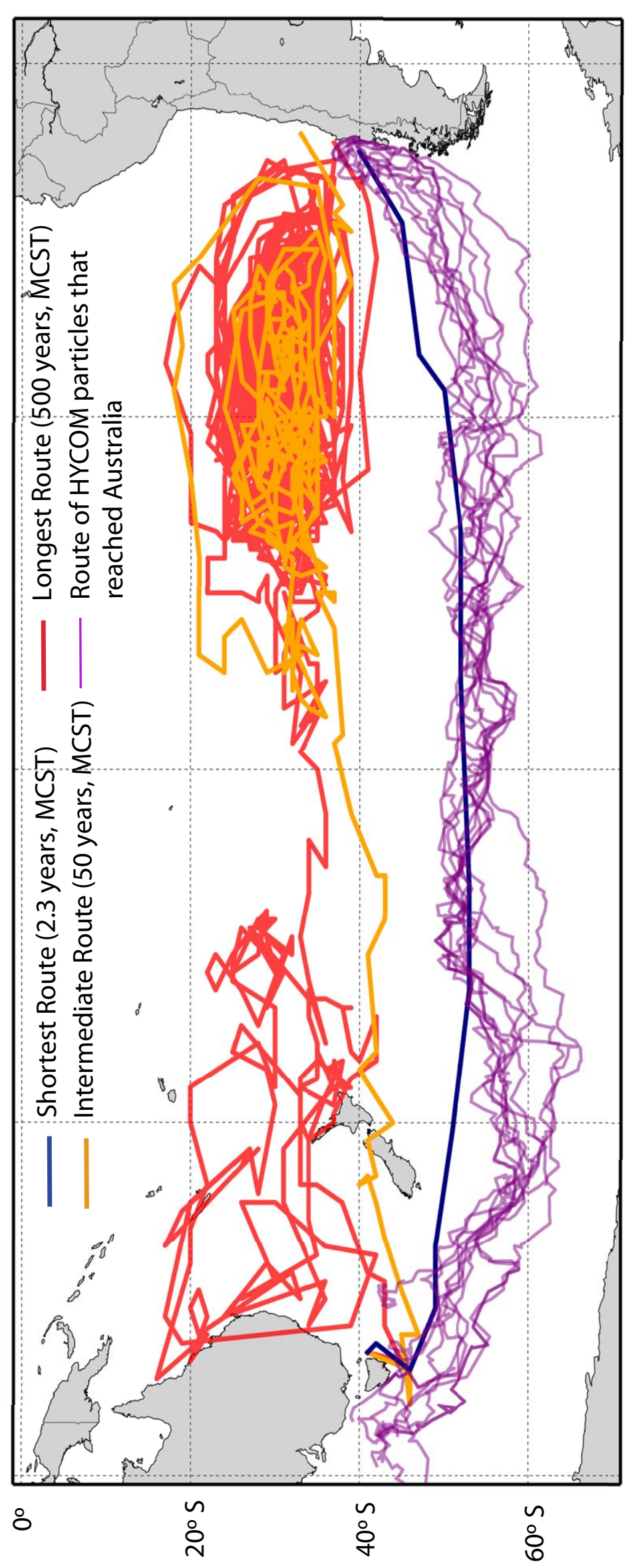

$3 \quad \stackrel{0}{\leq} . \underline{\underline{T}}$

은

离造.

वृ

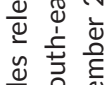

产

亲

으 은 군

है $\frac{\overline{\bar{\varepsilon}}}{\mathrm{\sigma}}$

언은 응

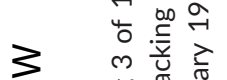

ㅇํㅇ 整

인

i

约 $\frac{0}{\pi} \sum_{0}^{\frac{\pi}{0}}$

$\sum \stackrel{0}{2}$

은 응

总过

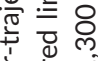

ฮั 검

을

늉

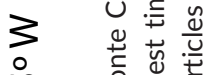

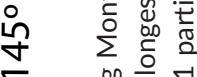

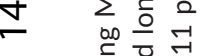

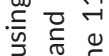

谣 离

쥰 유웜

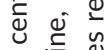

응

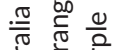

苞高

ع

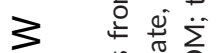

용

ㄷ

穵 部

.

कू⿻ 万丂

ป

○ 동

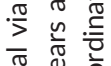

तु

ब

웜

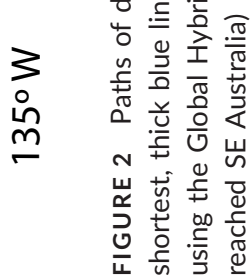




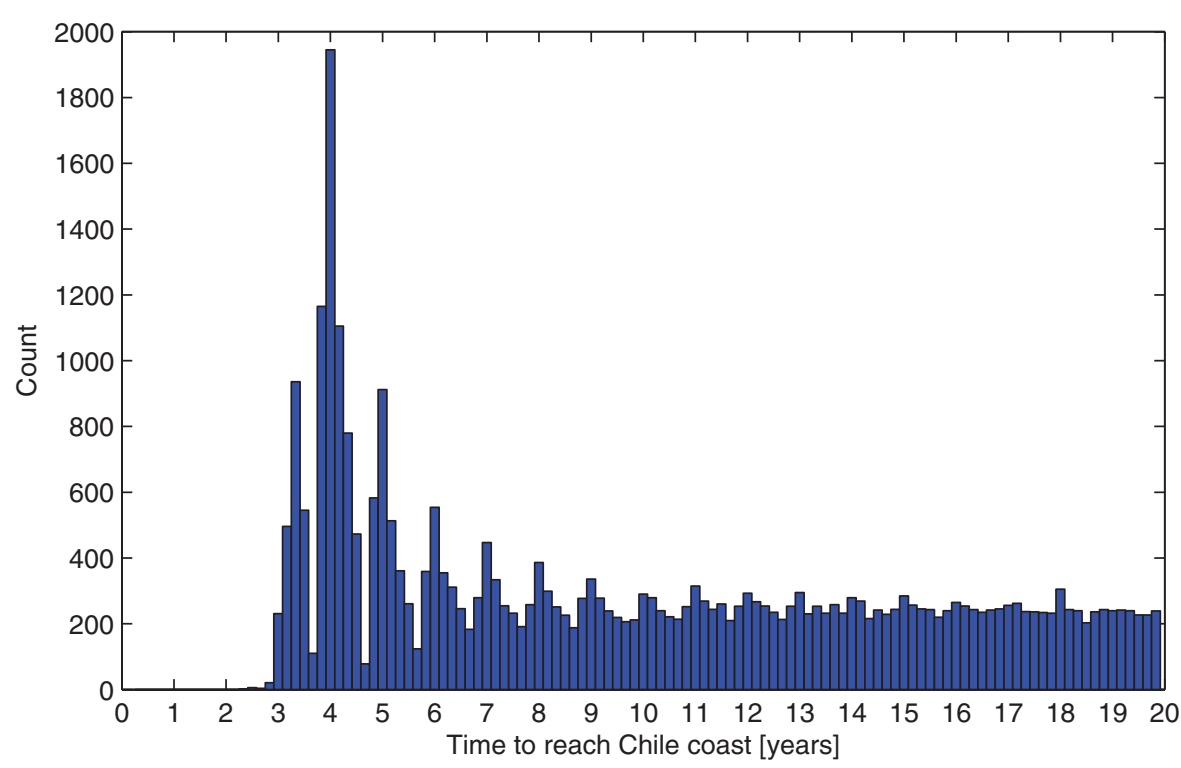

FIGURE 3 Number of Monte Carlos super-trajectory (MSCT) particles each year that reach central Chile from south-eastern Australia using super-trajectories oceanic dispersal model. The total amount of MCST particles released is 10 million

(3 months, Thomson et al., 2015); therefore, our estimates of the fragment numbers capable of arriving in Chile are likely to be overestimated. Oceanic models use restricted time frames (e.g. 1993-2013 for the backtracking model); however, over much longer periods the number of extreme events that facilitate pan-oceanic dispersal will increase, providing greater opportunities for LDD to occur, reducing the time required to reach Chile or facilitating longer fragment drifting time (Nathan, 2006). Bayesian assignment tests of the two Chilean clones indicated a relatively high probability that clone B originated from Port Phillip Bay in SE Australia. Dispersal across the southern Pacific Ocean is not unique and species distribution patterns between South America and Australasia are increasingly being linked to LDD (Sanmartin \& Ronquist, 2004; Waters, 2008). A growing number of marine species including kelps, gastropods, worms, oysters, crustaceans and tunicates appear to have recently arrived in Chile from Australasia via oceanic currents (Cumming, Nikula, Spencer, Waters, \& Crame, 2014; Foighil, Marshall, Hilbish, \& Pino, 1999; Fraser, Nikula, Spencer, \& Waters, 2009; Fraser, Nikula, Waters, 2011; Trickey, Thiel, \& Waters, 2016). Such predictable distribution patterns over a variety of species demonstrate viable dispersal pathways despite vast distances (Gillespie et al., 2012) and supports oceanic dispersal as a probable vector of seagrass dispersal across the Pacific. Given there is evidence of the presence of seagrass on the west coast of South America 5-20 Ma that has since disappeared (Velez-Juarbe, 2013), it is not unreasonable to expect that other dispersal events have occurred across the Pacific but populations have since died out.

While LDD of $\mathrm{H}$. nigricaulis vegetative fragments from SE Australia to Chile appears possible, an anthropogenic introduction provides an alternate dispersal mechanism. Trans-oceanic dispersal via shipping has led to the introduction of numerous marine and terrestrial species into new habitats far from their origin (Dawson, Gupta, \& England, 2005; Suarez, Holway, \& Case, 2001). In Chile, shipping has been suggested as a possible pathway for the recent introduction of the tunicate P. praeputialis (Castilla, Collins, Meyer, Guinez, \& Lindberg, 2002). Could $H$. nigricaulis also have been introduced to Chile via early shipping? There is a high probability that Chilean clone B originated in Port Phillip Bay, a major shipping port in SE Australia, providing evidence that shipping may have facilitated $H$. nigricaulis dispersal to Chile. Shipping records list 187 ships departing Port Phillip Bay for Chilean ports prior to the first recording of $H$. nigricaulis in 1864, providing a relatively high probability of dispersal. However, $\mathrm{H}$. nigricaulis does not fit easily into categories of organisms likely to be transported as fouling on ship hulls (Castilla \& Neill, 2009) and ballast water was not used in shipping prior to the first introduction in 1864 . However, seagrass may have been transported on ships via ballast (in rocks or sand), as mattress material or in anchor wells. Shipping time from SE Australia to Chile (average 50 days, Bader, 1974) corresponds much better than ocean currents with known viability of fragments in the water column; however, seeds and fragments desiccate quickly out of water (Pan et al., 2012), dramatically decreasing the likely number of viable propagules arriving in Chile. If the minimum probability of introduction is 1 in every 187 ships, then in the last 35 years where 46,340 ships have departed Port Phillip Bay for international ports, we would have expected to see approximately 248 further introductions worldwide. Yet there is only one other clone (Isla Damas) known outside of Australia, reaffirming the rare nature of $H$. nigricaulis establishment in Chile regardless of dispersal method.

Anthropogenic introductions are assumed to explain dispersal when oceanic currents are unable to explain distributions and often contain large genetic variation within the populations (Wilson, Dormontt, Prentis, Lowe, \& Richardson, 2009). Chilean populations of $H$. nigricaulis do not fit either of these scenarios suggesting shipping is an unlikely dispersal vector, but given the extreme rarity of oceanic dispersal, mechanisms that lie outside the generally accepted framework of anthropogenic introductions cannot be discounted. 
LDD provides opportunities to colonize new habitats and exploit resources, and facilitates species evolution (Sherman et al., 2016). The arrival of $\mathrm{H}$. nigricaulis on the west coast of South America not only demonstrates the occurrence of dispersal at the extreme end of the dispersal tail but also the benefits of LDD to individuals and ecosystems. In the absence of competition from adults, propagules that disperse large distances may have better survival and growth (Caughlin, Ferguson, Lichstein, Bunyavejchewin, \& Levey, 2014). South American $H$. nigricaulis patches cover an area of $2.27 \mathrm{~km}^{2}$ (Bahia Chascos), $1.20 \mathrm{~km}^{2}$ (Puerto Aldea) and $0.04 \mathrm{~km}^{2}$ (Isla Damas). The combined area of the single clone at Bahia Chascos and Puerto Aldea (clone A) represents one of the largest clones in the world, larger than most other extremely large clones such as the giant aspen Populus tremuloides $\left(0.43 \mathrm{~km}^{2}\right.$, Barnes, 1975) and the fungus Armillia bulbosa $\left(0.15 \mathrm{~km}^{2}\right.$, Smith, Bruhn, \& Anderson, 1992). Very large clones are indicative of seagrass species elsewhere such as Zostera marina $\left(0.006 \mathrm{~km}^{2}\right)$, while Posidonia oceanica meadows up to $15 \mathrm{~km}$ apart can have high densities of the same clone and are thought to have originated from a single clone over 1000s of years of clonal growth (Arnaud-Haond et al., 2012; Reusch, Bostrom, Stam, \& Olsen, 1999). These two H. nigricaulis clones have successfully colonized Chile and taken advantage of the absence of intraspecific competition to become some of the world's largest individual organisms.

The arrival of $\mathrm{H}$. nigricaulis has also had a profound impact on the ecosystem by creating new habitats that are utilized by a range of invertebrate and vertebrate species, altering species interactions and modifying the physical environment (González \& Edding, 1990; Leon \& Stotz, 2004; Ortiz, Jesse, Stotz, \& Wolff, 2003). Such impacts are typical of new arrivals from distant habitats and have shaped ecosystem structure and function both in naturally and anthropogenically dispersed species and highlight the importance of LDD at a global scale (Castilla et al., 2004; Trakhtenbrot, Nathan, Perry, \& Richardson, 2005). This is particularly the case for habitat-engineering species. For example, the recent arrival in northern Chile of the tunicate $P$. praeputialis, also from Australia, has been associated with increases in biodiversity in the areas it has colonized and opened new opportunities for human exploitation (Castilla et al., 2004, 2014). However, these potentially positive effects are offset by shifts in distribution and displacement of native species (Castilla et al., 2014; Griffiths, Hockey, Van Erkom Schurink, \& Le Roux, 1992). The colonization of coastal bays by $H$. nigricaulis has had similar effects on ecosystem function and services with increases in the production of exploited species in these systems and the development of a range of ecosystem services such as sediment and nutrient stabilization, high levels of production and carbon storage that may not otherwise occur (Orth et al., 2006; Ortiz et al., 2003). Understanding the provenance (either native or introduced) of habitat-forming species will provide valuable information for decisions on coastal management and conservation (York et al., 2017).

LDD is difficult to quantify due to rarity and reliance on unorthodox vectors leading to its dismissal in the past as a genuine determinate of species distributions. The presence of only two $\mathrm{H}$. nigricaulis clones in Chile, representing the largest marine clone in the world, demonstrates that species can disperse over vast distances despite the probability of arrival being extremely rare either via oceanic dispersal or via shipping. These results provide empirical evidence supporting LDD as a mechanism for species to expand their ranges and adapt to new environments.

\section{ACKNOWLEDGMENTS}

This work was funded by the Deakin University School of Environmental Sciences collaborative research grant (to T.S., C.S., P.Y. and P, M.) and an Australian Research Council DECRA Fellowship (to P.M). E.v.S. was partly supported by the European Research Council (ERC) under the European Union's Horizon 2020 research and innovation program (grant agreement no. 715386). N.P. acknowledges support from NOAA's Atlantic Oceanographic \& Meteorological Laboratory. Tatiana Manzur, Jose Pantoja, David Jofre and Alvaro Villena assisted in the field and Annalise Stanley assisted in the laboratory.

\section{DATA ACCESSIBILITY}

Data available from the Dryad Digital Repository: https://doi.org/10. 5061/dryad.85hro

\section{ORCID}

Timothy M. Smith (D) http://orcid.org/0000-0001-8612-8600

Bernardo R. Broitman (D) http://orcid.org/0000-0001-6582-3188

\section{REFERENCES}

Arnaud-Haond, S., Duarte, C. M., Diaz-Almela, E., Marbà, N., Sintes, T., Serrão, E. A., \& Bruun, H. H. (2012). Implications of extreme life span in clonal organisms: Millenary clones in meadows of the threatened seagrass Posidonia oceanica. PLoS One, 7(2), e30454.

Bader, T. M. (1974). Before the gold fleets: Trade and relations between Chile and Australia, 1830-1848. Journal of Latin American Studies, 6 (01), 35-58.

Bader, T. M. (1988). The roaring days: Trade and relations between Chile and Australia, 1849-1860. Journal of Australian Studies, 12(23), 29-44.

Barnes, B. V. (1975). Phenotypic variation of trembling aspen in Western North America. Forest Science, 21, 319-328.

Berković, B., Cabaço, S., Barrio, J. M., Santos, R., Serrão, E. A., \& Alberto, F. (2014). Extending the life history of a clonal aquatic plant: Dispersal potential of sexual and asexual propagules of Zostera noltii. Aquatic Botany, 113, 123-129.

Blake, S., \& Ball, D. (2001). Seagrass mapping Port Phillip Bay (Report No. 39). Queenscliff, Australia: Marine and Freshwater Resources Institute.

Castilla, J. C., \& Neill, P. E. (2009). Marine bioinvasions in the Southeastern Pacific: Status, ecology, economic impacts, conservation and management. In G. Rilov \& J. Crooks (Eds.), Biological invasions in marine ecosystems (pp. 439-457). Berlin Heidelberg: Springer.

Castilla, J. C., Collins, A. G., Meyer, C. P., Guinez, R., \& Lindberg, D. R. (2002). Recent introduction of the dominant tunicate, Pyura praeputialis (Urochordata, Pyuridae) to Antofagasta, Chile. Molecular Ecology, 11(8), 1579-1584.

Castilla, J. C., Lagos, N. A., \& Cerda, M. (2004). Marine ecosystem engineering by the alien ascidian Pyura praeputialis on a mid-intertidal rocky shore. Marine Ecology Progress Series, 268, 119-130.

Castilla, J. C., Manríquez, P. H., Delgado, A., Ortiz, V., Jara, M. E., Varas, M., \& Thuesen, E. V. (2014). Rocky intertidal zonation pattern in 
Antofagasta, Chile: Invasive species and shellfish gathering. PLoS One, 9(10), e110301.

Caughlin, T. T., Ferguson, J. M., Lichstein, J. W., Bunyavejchewin, S., \& Levey, D. J. (2014). The importance of long-distance seed dispersal for the demography and distribution of a canopy tree species. Ecology, 95(4), 952-962.

Chassignet, E. P., Hurlburt, H. E., Smedstad, O. M., Halliwell, G. R., Hogan, P. J., Wallcraft, A. J., ... Bleck, R. (2007). The HYCOM (hybrid coordinate ocean model) data assimilative system. Journal of Marine Systems, 65(1-4), 60-83.

Coyer, J. A., Hoarau, G., Kuo, J., Tronholm, A., Veldsink, J., \& Olsen, J. L. (2013). Phylogeny and temporal divergence of the seagrass family Zosteraceae using one nuclear and three chloroplast loci. Systematics and Biodiversity, 11(3), 271-284.

Cumming, R. A., Nikula, R., Spencer, H. G., Waters, J. M., \& Crame, A. (2014). Transoceanic genetic similarities of kelp-associated sea slug populations: Long-distance dispersal via rafting? Journal of Biogeography, 41(12), 2357-2370.

Dawson, M. N., Gupta, A. S., \& England, M. H. (2005). Coupled biophysical global ocean model and molecular genetic analyses identify multiple introductions of cryptogenic species. Proceedings of the National Academy of Sciences USA, 102(34), 11968-11973.

de Queiroz, A. (2005). The resurrection of oceanic dispersal in historical biogeography. Trends in Ecology and Evolution, 20(2), 68-73.

Dorken, M. E., \& Eckert, C. G. (2001). Severely reduced sexual reproduction in northern populations of a clonal plant, Decodon verticillatus (Lythraceae). Journal of Ecology, 89(3), 339-350.

Foighil, D. Ó., Marshall, B. A., Hilbish, T. J., \& Pino, M. A. (1999). Transpacific range extension by rafting is inferred for the flat oyster Ostrea chilensis. Biological Bulletin, 196(2), 122-126.

Fraser, C. I., Nikula, R., Spencer, H. G., \& Waters, J. M. (2009). Kelp genes reveal effects of subantarctic sea ice during the last glacial maximum. Proceedings of the National Academy of Sciences USA, 106(9), 3249-3253.

Fraser, C. I., Nikula, R., \& Waters, J. M. (2011). Oceanic rafting by a coastal community. Proceedings of the Royal Society B: Biological Sciences, 278(1706), 649-655.

Gillespie, R. G., Baldwin, B. G., Waters, J. M., Fraser, C. I., Nikula, R., \& Roderick, G. K. (2012). Long-distance dispersal: A framework for hypothesis testing. Trends in Ecology and Evolution, 27(1), 47-56.

González, S. A., \& Edding, M. E. (1990). Extension of the range of Heterozostera tasmanica (Martens ex Aschers.) den Hartog in Chile. Aquatic Botany, 38(4), 391-395.

Griffiths, C., Hockey, P., Van Erkom Schurink, C., \& Le Roux, P. (1992). Marine invasive aliens on South African shores: Implications for community structure and tropillc functioning. South African Journal of Marine Science, 12(1), 713-722.

Hall, L. M., Hanisak, M. D., \& Virnstein, R. W. (2006). Fragments of the seagrasses Halodule wrightii and Halophila johnsonii as potential recruits in Indian River Lagoon, Florida. Marine Ecology Progress Series, 310, 109-117.

Harwell, M. C., \& Orth, R. J. (2002). Seed bank patterns in Chesapeake Bay eelgrass (Zostera marina L.): A bay-wide perspective. Estuaries, 25(6), 1196-1204.

Källström, B., Nyqvist, A., Åberg, P., Bodin, M., \& André, C. (2008). Seed rafting as a dispersal strategy for eelgrass (Zostera marina). Aquatic Botany, 88(2), 148-153.

Kendrick, G. A., Orth, R. J., Statton, J., Hovey, R., Montoya, L. R., Lowe, R. J., ... Sinclair, E. A. (2017). Demographic and genetic connectivity:
The role and consequences of reproduction, dispersal and recruitment in seagrasses. Biological Reviews, 92(2), 921-938.

Kendrick, G. A., Waycott, M., Carruthers, T. J. B., Cambridge, M. L., Hovey, R., Krauss, S. L., .. Verduin, J. J. (2012). The central role of dispersal in the maintenance and persistence of seagrass populations. Biosience, 62(1), 56-65.

Kinlan, B. P., \& Gaines, S. D. (2003). Propagule dispersal in marine and terrestrial environments: A community perspective. Ecology, 84(8), 2007-2020.

Leon, R. I., \& Stotz, W. B. (2004). Diet and prey selection dynamics of Cancer polyodon in three different habitat types in Tongoy Bay, Chile. Journal of the Marine Biological Association of the United Kingdom, 84, 751-756.

Lett, C., Verley, P., Mullon, C., Parada, C., Brochier, T., Penven, P., \& Blanke, B. (2008). A Lagrangian tool for modelling ichthyoplankton dynamics. Environmental Modelling and Software, 23(9), 1210-1214.

Lumpkin, R., \& Pazos, M. (2007). Measuring surface currents with surface velocity program drifters: The instrument, its data, and some recent results. In A. Griffa, A. D. Kirwan Jr, T. Ozgokmen, A. J. Mariano, \& H. T. Rossby (Eds.), Lagrangian analysis and prediction of coastal and ocean dynamics (pp. 39-67). Cambridge: Cambridge University Press.

McMahon, K., van Dijk, K.-J., Ruiz-Montoya, L., Kendrick, G. A., Krauss, S. L., Waycott, M., ... Duarte, C. (2014). The movement ecology of seagrasses. Proceedings of the Royal Society B: Biological Sciences, 281 (1795), 20140878.

Nathan, R. (2006). Long-distance dispersal of plants. Science, 313(5788), 786-788.

Nathan, R., Getz, W. M., Revilla, E., Holyoak, M., Kadmon, R., Saltz, D., \& Smouse, P. E. (2008). A movement ecology paradigm for unifying organismal movement research. Proceedings of the National Academy of Sciences USA, 105(49), 19052-19059.

Orth, R. J., Carruthers, T. J. B., Dennison, W. C., Duarte, C. M., Fourqurean, J. W., Heck, K. L., ... Williams, S. L. (2006). A global crisis for seagrass ecosystems. Bioscience, 56, 987-996.

Ortiz, M., Jesse, S., Stotz, W., \& Wolff, M. (2003). Feeding behaviour of the asteroid Meyenaster gelatinosus in response to changes in abundance of the scallop Argopecten purpuratus in northern Chile. Archiv für Hydrobiologie, 157(2), 213-225.

Paetkau, D., Slade, R., Burden, M., \& Estoup, A. (2004). Genetic assignment methods for the direct, real-time estimation of migration rate: A simulation-based exploration of accuracy and power. Molecular Ecology, 13(1), 55-65.

Pan, J., Han, H., Jiang, X., Zhang, W., Zhao, N., Song, S., ... Li, X. (2012). Desiccation, Moisture Content and Germination of Zostera marina L. Seed. Restoration Ecology, 20(3), 311-314.

Phillips, R. C., Santelices, B., Bravo, R., \& McRoy, C. P. (1983). Heterozostera tasmanica (Martens ex aschers.) den Hartog in Chile. Aquatic Botany, 15(2), 195-200.

Piry, S., Alapetite, A., Cornuet, J.-M., Paetkau, D., Baudouin, L., \& Estoup, A. (2004). GENECLASS2: A software for genetic assignment and firstgeneration migrant detection. Journal of Heredity, 95(6), 536-539.

Putman, N. F., \& He, R. (2013). Tracking the long-distance dispersal of marine organisms: Sensitivity to ocean model resolution. Journal of the Royal Society Interface, 10(81), 20120979.

Putman, N. F., \& Naro-Maciel, E. (2013). Finding the 'lost years' in green turtles: Insights from ocean circulation models and genetic analysis. Proceedings of the Royal Society B: Biological Sciences, 280, 20131468.

Rannala, B., \& Mountain, J. L. (1997). Detecting immigration by using multilocus genotypes. Proceedings of the National Academy of Sciences USA, 94(17), 9197-9201. 
Reusch, T. B. H., Bostrom, C., Stam, W. T., \& Olsen, J. L. (1999). An ancient eelgrass clone in the Baltic. Marine Ecology Progress Series, 183, 301-304

Rodriguez, L. F. (2006). Can invasive species facilitate native species? Evidence of how, when, and why these impacts occur. Biological Invasions, 8(4), 927-939.

Sanmartin, I., \& Ronquist, F. (2004). Southern Hemisphere biogeography inferred by event-based models: Plant versus animal patterns. Systematic Biology, 53, 216-243.

Sherman, C. D. H., Lotterhos, K. E., Richardson, M. F., Tepolt, C. K., Rollins, L. A., Palumbi, S. R., \& Miller, A. D. (2016). What are we missing about marine invasions? Filling in the gaps with evolutionary genomics. Mar Biol, 163(10), 198-222.

Smith, M. L., Bruhn, J. N., \& Anderson, J. B. (1992). The fungus Armillaria bulbosa is among the largest and oldest living organisms. Nature, 356 (6368), 428-431.

Smith, T. M., York, P. H., Keough, M. J., Macreadie, P. I., Ross, D. J., \& Sherman, C. D. H. (2016). Spatial variation in reproductive effort of a Southern Australian seagrass. Marine and Freshwater Research, 120, 214-224.

Smith, T. M., York, P. H., Stanley, A. M., Macreadie, P. I., Keough, M. J., Ross, D. J., \& Sherman, C. D. H. (2013). Microsatellite primer development for the seagrass Zostera nigricaulis (Zosteraceae). Conservation Genetics Resources, 5(3), 607-610.

Stafford-Bell, R. E., Chariton, A. A., \& Robinson, R. W. (2015). Prolonged buoyancy and viability of Zostera muelleri Irmisch ex Asch. vegetative fragments indicate a strong dispersal potential. Journal of Experimental Marine Biology and Ecology, 464, 52-57.

Suarez, A. V., Holway, D. A., \& Case, T. J. (2001). Patterns of spread in biological invasions dominated by long-distance jump dispersal: Insights from Argentine ants. Proceedings of the National Academy of Sciences USA, 98(3), 1095-1100.

Thomson, A. C. G., York, P. H., Smith, T. M., Sherman, C. D. H., Booth, D. J., Keough, M. J., ... Macreadie, P. I. (2015). Seagrass viviparous propagules as a potential long-distance dispersal mechanism. Estuaries and Coasts, 38(3), 927-940.

Trakhtenbrot, A., Nathan, R., Perry, G., \& Richardson, D. M. (2005). The importance of long-distance dispersal in biodiversity conservation. Diversity and Distributions, 11(2), 173-181.

Trickey, J. S., Thiel, M., \& Waters, J. M. (2016). Transoceanic dispersal and cryptic diversity in a cosmopolitan rafting nudibranch. Invertebrate Systematics, 30(3), 290-301.

van Sebille, E. (2014). Adrift.org.au - A free, quick and easy tool to quantitatively study planktonic surface drift in the global ocean. Journal of Experimental Marine Biology and Ecology, 461, 317-322. van Sebille, E., Beal, L. M., \& Johns, W. E. (2011). Advective time scales of Agulhas leakage to the North Atlantic in surface drifter observations and the 3D OFES model. Journal of Physical Oceanography, 41, 1026-1034.

Velez-Juarbe, J. (2013). Ghost of seagrass past: Using sirenians as a proxy for historical distribution of seagrasses. Palaeogeography, Palaeoclimatology, Palaeoecology, 400, 41-49.

Vilà, M., Espinar, J. L., Hejda, M., Hulme, P. E., Jarošík, V., Maron, J. L., ... Pyšek, P. (2011). Ecological impacts of invasive alien plants: A meta-analysis of their effects on species, communities and ecosystems. Ecology Letters, 14(7), 702-708.

Waters, J. M. (2008). Driven by the West Wind Drift? A synthesis of southern temperate marine biogeography, with new directions for dispersalism. Journal of Biogeography, 35(3), 417-427.

Wilson, J. R. U., Dormontt, E. E., Prentis, P. J., Lowe, A. J., \& Richardson, D. M. (2009). Something in the way you move: Dispersal pathways affect invasion success. Trends in Ecology and Evolution, 24(3), 136-144.

York, P. H., Smith, T. M., Coles, R. G., McKenna, S. A., Connolly, R. M., Irving, A. D., ... Whitehead, S. (2017). Identifying knowledge gaps in seagrass research and management: An Australian perspective. Marine Environmental Research, 127, 163-172.

\section{BIOSKETCH}

Тімотну SмIтH is an ecologist whose work investigates resilience, connectivity and landscape processes in marine ecosystems. Tim's primary interests have been focused on seagrass habitats but have also included other nearshore habitats and fish and invertebrates. Currently Tim has projects investigating the impacts of seagrass herbivores and estuarine foodwebs.

\section{SUPPORTING INFORMATION}

Additional Supporting Information may be found online in the supporting information tab for this article.

How to cite this article: Smith TM, York PH, Broitman BR, et al. Rare long-distance dispersal of a marine angiosperm across the Pacific Ocean. Global Ecol Biogeogr. 2018;27:487-496. https:// doi.org/10.1111/geb.12713 